Article

\title{
Evaluation of Mechanical and Energetic Properties of the Forest Residues Shredded Chips during Briquetting Process
}

\author{
Kamil Roman $^{1, *(\mathbb{D})}$, Jan Barwicki ${ }^{2} \mathbb{D}$, Witold Rzodkiewicz ${ }^{3}(\mathbb{D})$ and Mariusz Dawidowski $^{3}(\mathbb{D}$ \\ 1 Institute of Wood Sciences and Furniture, Warsaw University of Life Sciences, 166 Nowoursynowska St., \\ 02-787 Warsaw, Poland \\ 2 Institute of Technology and Life Sciences, Warsaw Branch, 32 Rakowiecka St., 02-532 Warsaw, Poland; \\ jbarwicki@gmail.com \\ 3 Central Office of Measures, 2 Elektoralna St., 00-139 Warsaw, Poland; witold.rzodkiewicz@gum.gov.pl (W.R.); \\ mariusz.dawidowski@gum.gov.pl (M.D.) \\ * Correspondence: kamil_roman@sggw.edu.pl
}

Citation: Roman, K.; Barwicki, J.; Rzodkiewicz, W.; Dawidowski, M. Evaluation of Mechanical and Energetic Properties of the Forest Residues Shredded Chips during Briquetting Process. Energies 2021, 14, 3270. https://doi.org/10.3390/ en14113270

Academic Editor: Xiaolin Wang

Received: 10 April 2021

Accepted: 30 May 2021

Published: 3 June 2021

Publisher's Note: MDPI stays neutral with regard to jurisdictional claims in published maps and institutional affiliations.

Copyright: (C) 2021 by the authors. Licensee MDPI, Basel, Switzerland. This article is an open access article distributed under the terms and conditions of the Creative Commons Attribution (CC BY) license (https:// creativecommons.org/licenses/by/ $4.0 /)$.

\begin{abstract}
The briquetting process is one of methods of solid biofuel production. During the briquetting of raw material, it can be noticed that material is viscoelastic, and reflects the effect on the volume and the final effect of the agglomerate during mentioned treatment. The research aimed to evaluate the mechanical and energetic properties of shredded pine forest residues during the briquetting process. The shredded fragments of the forest residues were compacted by the principal stresses with determination of the energy value consumed during the briquetting process. Tests were carried out using a specially designed compacting tube, with additional equipment directly mounted on the testing machine. The compaction process was carried out using the presented material and through continuous monitoring of the process parameters. During the study, it was estimated that the moisture content of the compacted material should be equal from 10 to $15 \%$. The calculated average value of the unit energy consumption during the briquetting process (WB) was equal to $0.14 \mathrm{MJ} \cdot \mathrm{kg}^{-1}$. In future research, the mathematical model can serve as an algorithm in a computer program in order to calculate the flow of biomass in the extrusion process.
\end{abstract}

Keywords: forest residues; briquetting; mechanical properties

\section{Introduction}

Natural raw materials for energy purposes have become significantly popular in recent years [1]. In particular, forest biomass [2] has been used more as a fuel in various types of heating installations in Poland. The amount of biomass increases with properly conducted forest management, the development of agricultural production, and the growing scale of post-production waste. The increased interest in this type of raw materials is caused by the possibility of energy management of biodegradable waste, which, in direct combustion processes, emits less pollutants than fossil fuels. Mechanical modeling of the briquetting process is the basis of this research. As the process is very complex and affected by various factors, few achievements have occurred [3].

The basic method of preparing solid biomass for energy purposes is the compaction of the shredded residues of the raw material into a briquette form [4]. The briquetting process is one of the methods of producing solid biofuels, the technology of which consists of pressure compaction and the consolidation of shredded materials from feedstocks. During the process, pressure is used that during briquetting removes the air from the intermolecular space. This causes the gradual densification of the material charge in the briquetting chamber of the briquetting press [5].

The literature describes and explains the physical reactions taking place during the compaction process, which are the result of the interactions of various material [6] and process [7] parameters. The briquetting process can also be considered in a mechanical 
context, but because of its complexity, analyses in this area are less frequently described in the literature. Research in a similar field was conducted by Holm and his team [8,9], developing a mathematical model characterizing the increase of pressure during the process of densifying plant materials. In the research of Xia [10], the model of the torque occurring during the straw briquetting process was described.

The pressure generated during the briquetting process depends on the press technical parameters and the manufactured briquette dimensions. The data presented in the table below show a very large range of unit pressure values as recommended by individual authors. This range was about 5 to more than $100 \mathrm{MPa}$. This means that determining the appropriate value of the unit pressure in the briquetting process is a difficult and troublesome procedure, additionally dependent on the irregularity and length of the fraction (the degree of grinding of the material), as well as on other factors occurring during the process, such as the type of biomass and its moisture content [11]. According to some authors, the briquetting of forest residues should be performed under pressure from 45 to $60 \mathrm{MPa}[5,12,13]$. The unit pressure values reported in the literature are presented in Table 1.

Table 1. Unit pressure values reported in the literature.

\begin{tabular}{ccc}
\hline No. & Unit Pressure, MPa & References \\
\hline 1 & $45-50$ & {$[5]$} \\
2 & $45-113$ & {$[12]$} \\
3 & $17-47$ & {$[13]$} \\
4 & 5 & {$[14]$} \\
5 & $10-50$ & {$[15]$} \\
6 & $30-60$ & {$[16]$} \\
7 & $25-100$ & {$[17]$} \\
8 & $27.6-41.4$ & {$[18]$} \\
9 & $9.8-98$ & {$[19]$} \\
10 & $25.5-88.3$ & {$[20]$} \\
11 & $32.4-52$ & {$[21]$} \\
12 & 13.7 & {$[23]$} \\
13 & $29.4-58.8$ & {$[24]$} \\
14 & $13-39$ & {$[25]$} \\
15 & $32-38$ & \\
\hline
\end{tabular}

Increased pressure in conjunction with correspondingly high frictional forces can be the cause of an increased temperature of up to $150{ }^{\circ} \mathrm{C}$. The high-temperature condition can be artificially maintained using specialized heaters mounted outside on the surface. In some cases, the increased temperature is needed to create the hardened surface of the produced briquette and increase its density [26]. This practice can be confirmed by the research of Kaliyan and Morey [27], who used ground particles (from 0.5 to $1.0 \mathrm{~mm}$ ) of corn, alfalfa, wheat straw, sawdust, and animal feed materials with a moisture content of 8 to $20 \%$, to produce briquettes characterized by high durability and density at temperatures of 65 to $100{ }^{\circ} \mathrm{C}$. A temperature of up to $120^{\circ} \mathrm{C}$ was used during briquetting by another team of researchers [28], whose research, besides the confirmation of the relationship discussed above, additionally showed a lower energy consumption and shorter compaction time for shredded rice straw.

Mechanical analyses of the raw material briquetting process are extremely difficult to develop because of the multi-phase nature of the material. The shredded material, according to its structure, can be classified as a loose material. The specification of the material structure makes their mechanical properties different from the solid materials. Every solid material under compacted stress must deform when exceeding the yield point of the process. According to the assumptions, the external factors of the material and process parameters can impact the mechanical properties of the compacted material. 
The paper presents the characteristics of the mechanical properties of shredded forest residues that were subjected to the thickening process, determining the principal stresses for stocked heterogeneous multiphase materials. To assess the occurring material irregularities affecting the briquetting process, selected parameters of the material (material moisture) and process parameters (process temperature) were analyzed.

\section{Materials and Method}

\subsection{Forest Residues}

The material that was studied was collected from the forest area in a dry coniferous forest habitat. According to the appraisal description, Scots pine trees (Pinus sylvestris L.), aged 70-80 years, predominated in the study area. The material subjected to the analysis was logging residue from the M2 assortment of the pine species. The raw material was obtained as waste as a result of logging in forest areas in the Chojnice Forest District (Poland). It was characterized by a large number of needles, small twigs, poorly developed bark, and thicker elements. The analyzed raw material differed from the materials used in the industrial production of briquettes.

After cutting, the obtained forest residues were characterized by a large diversity in terms of the dimensions and structure of individual elements. The feedstock consisted of needles, twigs of various diameters, and smaller and larger wood fragments obtained during the manipulation of medium-sized wood (rollers and wood pieces up to $1 \mathrm{~m}$ long with visible defects). This stack was characteristic of this material and the method of its acquisition. The freshly cut forest residues were transported in their original state and then shredded using machine chipping forest residues. The freshly obtained raw material was prepared using an RTB13 woodchipper machine. The raw material after shredding was characterized by a significant diversity of composition (multi-phase loose structure), in which it was possible to specify the sand, bark, moss, and pine needles. The forest residues before and after shredding are shown in Figure 1.

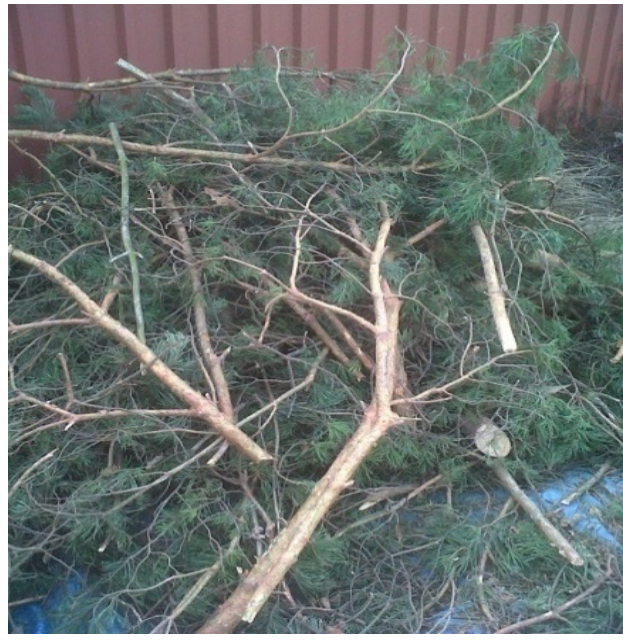

(a)

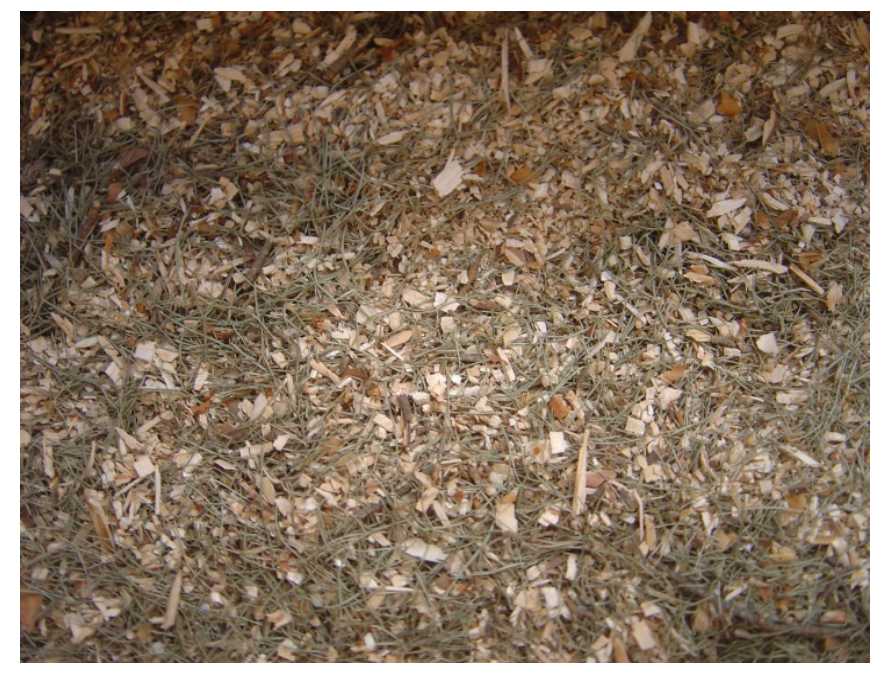

(b)

Figure 1. Scots pine (Pinus sylvestris L.) forest residues: (a) natural state; (b) after shredding.

The construction of the woodchipper machine mechanism allowed for obtaining chips with dimensions suitable for the diameter of the compacting head. The length of the produced fractions depended on the composition of the logging residues. The maximum branch diameter at the lower end of the M2 assortment, according to the standard description, could not exceed $70 \mathrm{~mm}$, together with the bark. As a result of shredding, the largest elements (their length) of the raw material did not exceed $16 \mathrm{~mm}$. The obtained logging residues were shredded and prepared according to the assumed 
parameters. The size of the produced fractions was determined by the screen, mounted inside the woodchipper machine, and the length did not exceed $16 \mathrm{~mm}$. According to the research procedure, fragmented logging residues had to be separated and dried to 10, 15, and $20 \%$ moisture contents. The raw material moisture content was evaluated using a laboratory dryer.

\subsection{Prototype Compacting Tube}

The mechanical properties of the raw material were determined using specially prepared laboratory equipment, which contained a prototype compacting tube and some additional sensors. The compacting tube with additional sensors was mounted on the Veb Thuringer Industriewerk Rauenstein testing machine (Germany). The testing machine could produce about $63 \mathrm{MPa}$ of pressure.

To verify the correctness of the strength calculations, SolidWorks software (USA) was used during the design of the compacting tube. The program was based on the finite element method (FEM), supporting the research and scientific analyses of the mechanical issues through the characteristics of the distribution of stresses, strains, and displacements $[29,30]$. During calculations, the maximum compaction strength, geometric parameters, and strength properties of the material used were taken into account. The view of the compacting head with the location of the heaters and the strength model of the analyzed compacting head are presented in Figure 2.

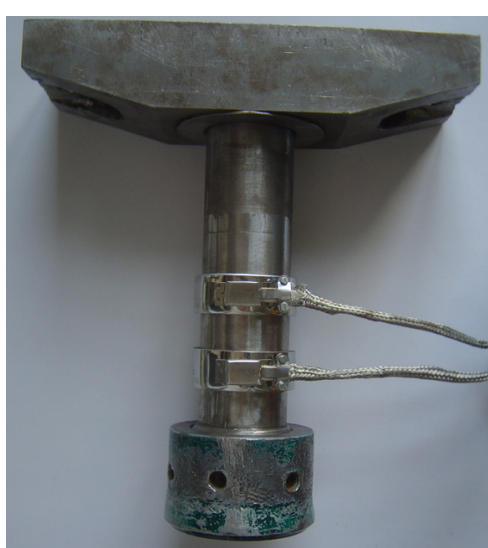

(a)

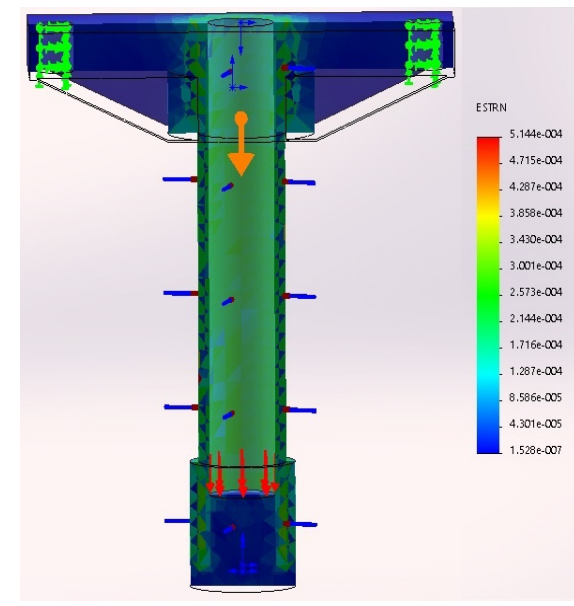

(b)

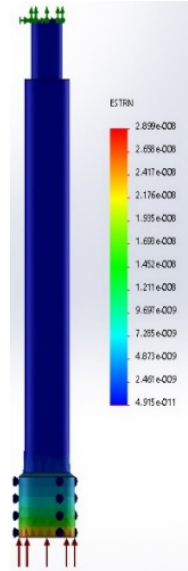

(c)

Figure 2. Research apparatus for measuring forest biomass compaction with an installed compacting tube: (a) compacting tube; (b) analysis of the construction of a prototype compacting tube; (c) analysis of the structure of the compacting head piston.

The structure of the compacting head was modeled based on an algorithm analyzing the isotropic nature of the material. Young's modulus of elasticity, suitable for tool steel, was adopted in the calculations, $E=205 \times 10^{3} \mathrm{MPa}$, with a Poisson's ratio of $v=0.3$. The FEM analysis method, at the very beginning of the project design, allowed for eliminating design errors. The main effect of the program's work was to indicate (using colors) the places most and least exposed to stress. The most sensitive places were marked in red, which turned into a blue shade as the probability of deformation decreased.

It can be noticed that the most vulnerable place of the tube to deformation was the sleeve and its threaded connections with the support and the cover. The resulting reactions in the thickening head with the assumed Huber von Mises plasticity condition amounted to an average of $90 \mathrm{MPa}$ and did not exceed the safety factor equal to $620.8 \mathrm{MPa}$. In the case of a piston, the structural element most prone to deformation was the working surface in contact with the material to be compacted. 
The main element of the prototype compacting tube was a cylindrical uniaxial compression chamber with a diameter of $\varnothing 45 \mathrm{~mm}$ and a height of $300 \mathrm{~mm}$. The installed band heaters allowed for maintaining the process temperature at the level of 73 and $103{ }^{\circ} \mathrm{C}$. During the research, the shredded raw material was placed in the heated chamber of the prototype compacting tube. Forcing the punch inside the chamber caused the shredded raw material to compress. The additional sensors set measured the temperature, strength, and displacement. The values of the research parameters are presented in Table 2.

Table 2. Values of research parameters.

\begin{tabular}{cc}
\hline Parameters & Value \\
\hline Temperature & 103 and $73{ }^{\circ} \mathrm{C}$ \\
Diameter of the mold $(\mathrm{mm})$ & 45 \\
Max pressure $(\mathrm{MPa})$ & 63 \\
Compression velocity $(\mathrm{mm} / \mathrm{min})$ & 2.5 \\
\hline
\end{tabular}

The obtained temperature of the heater mounted on the compacting tube had no major influence on the pressure measurement. The simulation of the process in various working environments made it possible to characterize the most appropriate process conditions occurring during the production of the briquettes. Micanite type heaters (GO-GO-04349) of $25 \mathrm{~mm}$ high were mounted on the compacting tube. In the future, the heater could be equipped with additional equipment that maintains the constant temperature of the heater. The diameter of the heater was adjustable. However, the standard adjustment was $60(\mathrm{~mm})$, and extended up to $120(\mathrm{~mm})$. The emitted temperature of the mounted heater did not affect the measurement of the pressure sensors. Therefore, two heaters were installed between the sensors.

\subsection{Physical Parameters}

The research was proceeded by compacting the shredded forest residues, whose fractions did not exceed $16 \mathrm{~mm}$ in length. Each analysis was provided three different samples with a natural particle size composition. The tested material was analyzed with the assumed parameters. The methodology assumed the compression in the prototype compacting tube in three repeats for every sample variation. The number of repetitions was sufficient to observe the statistical repeatability of the course of the pressure function over time.

During laboratory studies of the forest residues of shredded briquetting chips, the moisture of the material was taken into account. The measurement of the material moisture and its influence on the briquetting process of the forest residues of shredded chips has been described in another publication [31]. The same publication also described the behavior of the raw material in the briquetting process at different process temperatures. In light of the statistical analyses and our own experience, it was found that the moisture content of the raw material in the range of $10-20 \%$ did not show any significant correlation during the briquetting process itself $[31,32]$. The values of the tested material parameters are summarized in Table 3.

Table 3. Material parameter values.

\begin{tabular}{cc}
\hline Parameters & Value \\
\hline Moisture content & 10,15 and $20 \%$ \\
Material weight in a single briquetting & $200 \mathrm{~g}$ \\
Pressure holding time (s) & $30-60$ \\
\hline
\end{tabular}

The briquetting process was also analyzed according to the energy consumption. The determination of work $W_{(\tau, \varphi)}$ corresponded to the energy consumption for each performed compacting operation. The amount of energy used was determined by integrating the 
thrust force $(N)$ as a function of the piston displacement $(l)$. The energy consumption resulting from the compaction process of shredded forest residues, under certain conditions, was calculated using Formula (1).

$$
W_{(\tau, \varphi)}=\int_{0}^{0.001 \cdot l} N(x) d x
$$

The calculation is the product of load and displacement. On the plot, the load versus time is presented, which allowed for presenting the moment of release that occurs after releasing the piston, allowing for further action of the compacted material to be observed. To obtain the course as a function of the displacement function, the time value should be multiplied by the constant speed of the piston displacement, equal to $2 \mathrm{~mm} \cdot \mathrm{s}^{-1}$.

\section{Results}

The research of the shredded forest residue compaction with natural fraction distribution was performed at process temperatures equal to 22 and $73{ }^{\circ} \mathrm{C}$. The tests were performed at assumed humidity levels of 10,15 , and $20 \%$. The measurement of the thickening force values changed during the operation with different parameters of the raw material and process parameters, and the methodology was performed in a specially prepared tube. The shredded chips of the forest residues in the original (obtained as a result of grinding) particle size were composed. During the analysis, it was noticed that the final volume of briquettes produced without the use of heaters was differed from the volume of briquettes produced at an elevated temperature in the compaction process. The briquettes formed during the compaction process from the shredded chips of the forest residues, as shown in Figure 3.

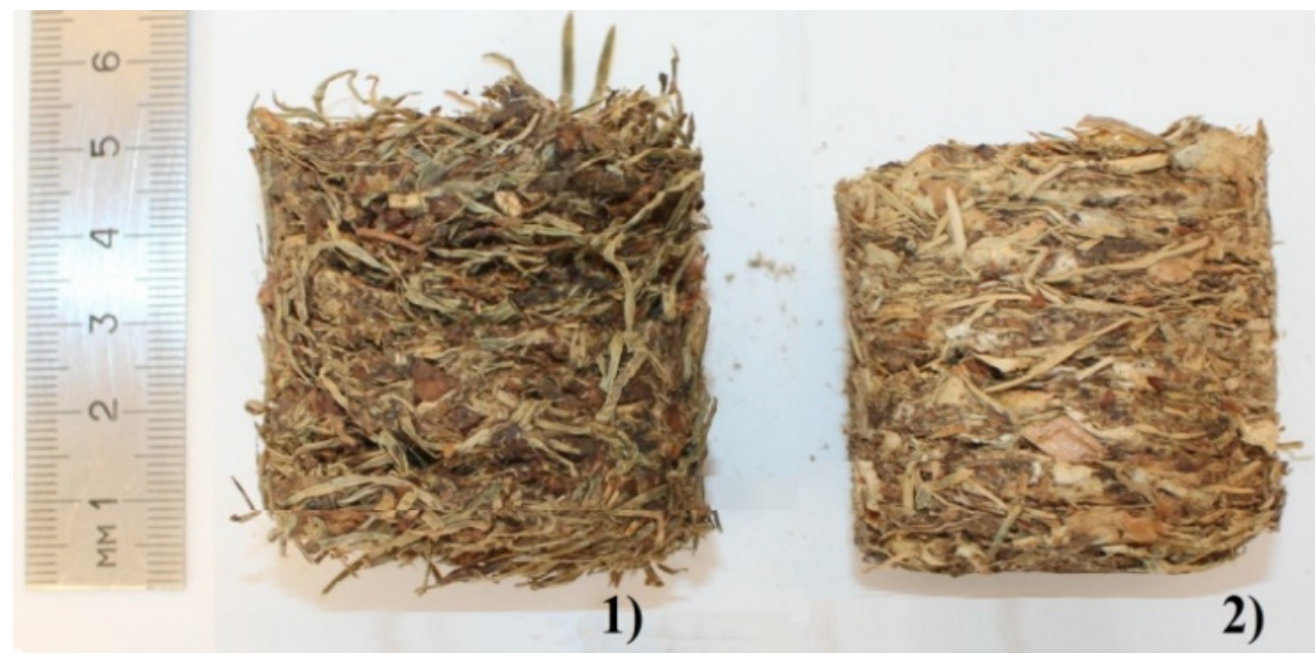

Figure 3. Briquettes from the shredded chips of forest residues from the primary composition, formed at a temperature of (1) $22{ }^{\circ} \mathrm{C}$ and $(2) 73{ }^{\circ} \mathrm{C}$.

The presented study describes the function of utilized pressure of the shredded chips of forest residues during the compaction process. The defined function, according to similar research in the literature [28], was divided into three parts depending on the mechanical phenomena occurring in the particle structure. Part A presents a linear force increase. The pressure value was equal to $0.02 \mathrm{MPa}$ and did not exceed $2 \mathrm{MPa}$. Part B shows plastic changes in the structure of the raw material particles. Part $C$ represents the pressure drop inside the head chamber, causing particle relaxation and stabilization of the briquette structure.

The diagram presents the briquetting, where the displacement can be represented as the sum of parts A and B (from 0.01 to $63 \mathrm{MPa}$ ). Part A and B reflect the nature of briquette compaction, where the compaction time is proportional to the value of pressure. 
An extended briquetting time corresponded to briquettes of a higher density [24,28]. Part $\mathrm{C}$ represents the relaxation zone, characterized by a pressure drop after the piston stopped. In the figure below, the displacement of the piston was recorded during the process to make the relaxation process (part C) more visible. The comparison of the briquetting time to the compaction stress for samples with the assumed material and process parameters is presented in Figure 4.

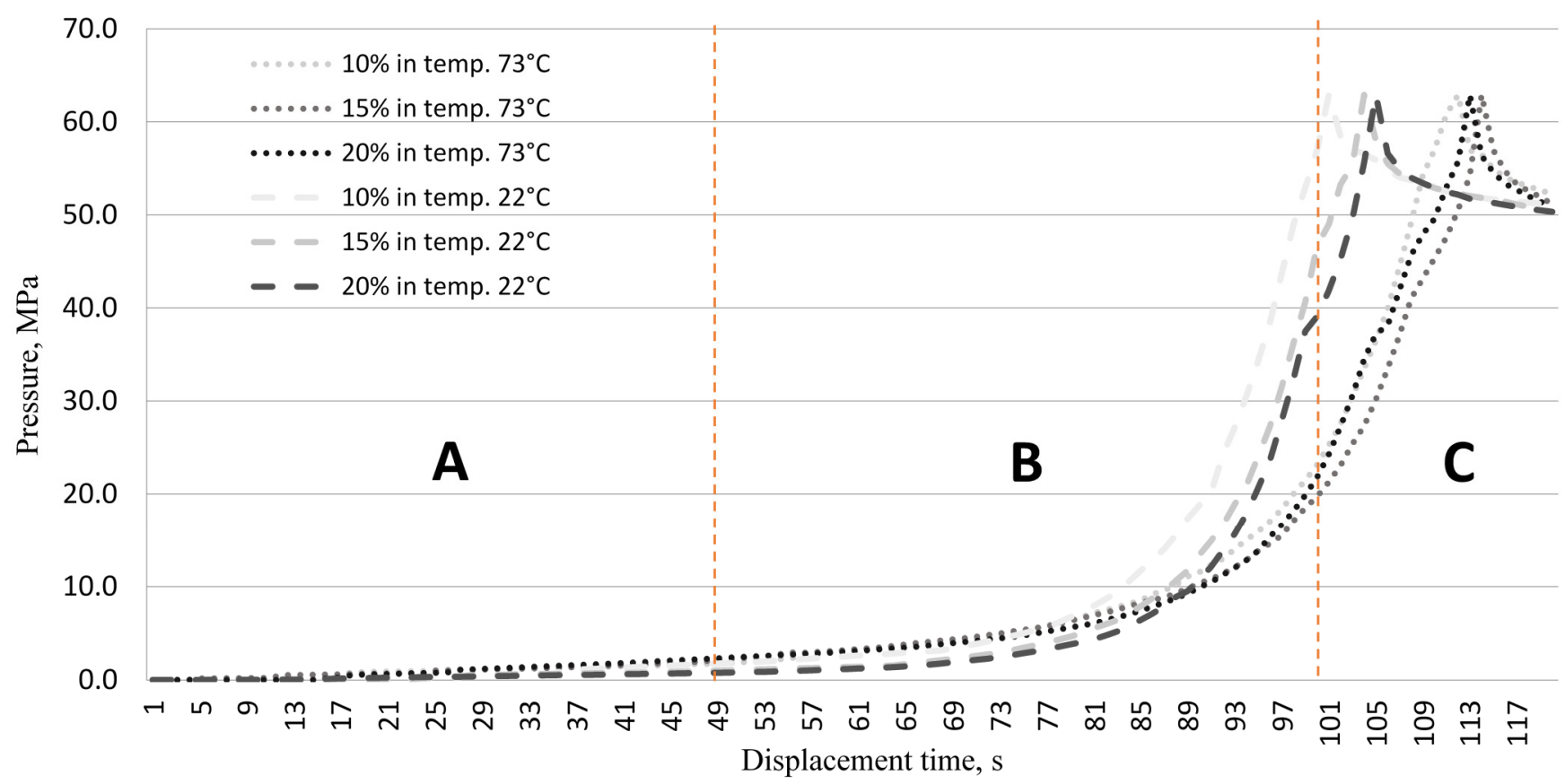

Figure 4. The resultant of strengths during the briquetting of the forest residue shredded chips at a temperature of 22 and $73^{\circ} \mathrm{C}$ with a humidity of 10,15 , and $20 \%$.

The characteristics are the resultant force of the piston movement and material resistance under the assumed boundary conditions processes humidity and temperature). The contractual limit of proportionality basing on the linear course of stresses during the compaction of the forest residues shredded chips compaction process was determined. The separated resultant forces in part A are presented in Figure 5.

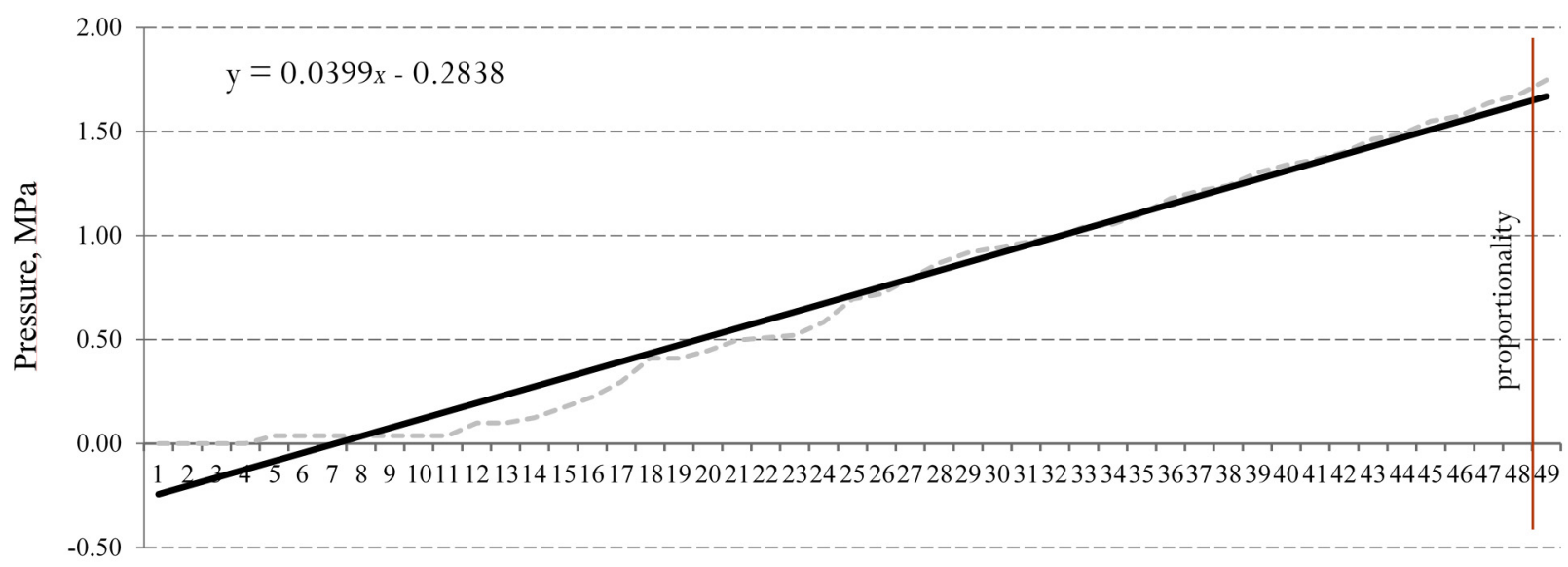

Displacement time, $\mathrm{s}$

Figure 5. The resultant strengths in part A. 
During the research, the modulus of elasticity was found, which was a polynomial of a function in the diagram. The value of the elasticity module was equal to $E=1.2 \mathrm{MPa}$, and was converted from the function of $y=0.0399 x-0.2838$. The coefficient of determination resulted in $R^{2}=0.9781$. The high level of match responded to the appropriately selected level of the proportionality interval. The transformation of the formulas used for the elasticity module counted in the elastic-linear structure is given below in Formulas (2) and (3).

$$
\begin{gathered}
\sigma=\frac{E}{l} \Delta l \\
E=0.0399 \times l=1197 \mathrm{MPa}
\end{gathered}
$$

The arithmetic function describing the thickening process of the forest residue shredded chips was adjusted to the fifth-degree polynomial $\left(y=a x^{5}+b x^{4}+c x^{3}+d x^{2}+e x+f\right)$. The model was estimated using the Gauss-Newton least-squares method. The summary of the evaluation of the arithmetic function coefficients is presented in Table 4.

\begin{tabular}{|c|c|c|c|c|c|c|c|c|}
\hline \multicolumn{2}{|c|}{$\begin{array}{l}\text { Physico-Chemical Parameters }(\tau) \\
\text { and the Briquetting Process }(\varphi) 1\end{array}$} & \multicolumn{7}{|c|}{ Coefficients of the Arithmetic Function } \\
\hline \multirow{2}{*}{$\begin{array}{l}\text { Feedstock } \\
\text { Moisture, \% }\end{array}$} & \multirow{2}{*}{$\begin{array}{c}\text { Process } \\
\text { Temperature, }{ }^{\circ} \mathrm{C}\end{array}$} & \multicolumn{6}{|c|}{ Significance Level ( $p$ ) } & \multirow{2}{*}{$\begin{array}{c}\text { Coefficient of } \\
\text { Determination }\left(R^{2}\right)\end{array}$} \\
\hline & & $a$ & $b$ & $c$ & $d$ & $e$ & $f$ & \\
\hline 10 & \multirow{3}{*}{22} & $10^{-5}$ & $10^{-5}$ & $10^{-5}$ & $2 \times 10^{-13}$ & $2 \times 10^{-8}$ & $9 \times 10^{-4}$ & 0.996 \\
\hline 15 & & $10^{-5}$ & $10^{-5}$ & $10^{-5}$ & $1 \times 10^{-11}$ & $5 \times 10^{-7}$ & $3 \times 10^{-3}$ & 0.996 \\
\hline 20 & & $10^{-5}$ & $10^{-5}$ & $10^{-5}$ & $10^{-5}$ & $10^{-5}$ & $3 \times 10^{-4}$ & 0.998 \\
\hline 10 & \multirow{3}{*}{73} & $10^{-5}$ & $10^{-5}$ & $10^{-5}$ & $10^{-5}$ & $10^{-5}$ & $6 \times 10^{-4}$ & 0.997 \\
\hline 15 & & $10^{-5}$ & $10^{-5}$ & $10^{-5}$ & $10^{-5}$ & $1 \times 10^{-14}$ & - & 0.993 \\
\hline 20 & & $10^{-5}$ & $10^{-5}$ & $10^{-5}$ & $10^{-5}$ & $10^{-5}$ & $5 \times 10^{-5}$ & 0.997 \\
\hline
\end{tabular}

Table 4. Summary of the evaluation of the coefficients of the arithmetic function.

The results of the statistical analyzes confirmed the right choice of the fifth-degree polynomial validity, intending to adjust it to the function of the compaction force during the briquetting process. The exception was the function determining the briquetting process of the material with raw material moisture of $15 \%$ at a process temperature of $73{ }^{\circ} \mathrm{C}$. Therefore, the use of a fourth-order polynomial was required. In the trend line of the fourth-order polynomial case $\left(y=a x^{4}+b x^{3}+c x^{2}+d x+e\right)$, all values were significant, with the matching coefficient $R^{2}$ having a value of 0.993 . Using the time change of the compaction force, the value of the total work of the material compaction process $\left(W_{(\tau, \varphi)}\right)$ was determined for various raw material and process parameters. The values of the total compaction work with specific parameters are presented in Table 5.

Table 5. Values of total compaction work with specific parameters.

\begin{tabular}{ccc}
\hline Total Work Performed under Specified Conditions $\left(\boldsymbol{W}_{(\tau, \boldsymbol{\varphi})}\right)$ & Value, J \\
\hline$W_{\left(10 \%, 22^{\circ} \mathrm{C}\right)}=\int_{0}^{0.001 \cdot l} 2.92 \times 10^{9} x^{5}-1.3 \times 10^{9} x^{4}+2.1 \times 10^{8} x^{3}-1.4 \times 10^{7} x^{2}+3.5 \times 10^{5} x-1.9 \times 10^{3}$ & 2118.45 \\
$W_{\left(15 \%, 22^{\circ} \mathrm{C}\right)}=\int_{0}^{0.001 \cdot l} 2.97 \times 10^{9} x^{5}-1.3 \times 10^{9} x^{4}+2.02 \times 10^{8} x^{3}-1.3 \times 10^{7} x^{2}+3.2 \times 10^{5} x-1.7 \times 10^{3}$ & 234.75 \\
$W_{\left(20 \%, 22^{\circ} \mathrm{C}\right)}=\int_{0}^{0.001 \cdot l} 3.5 \times 10^{9} x^{5}-1.5 \times 10^{9} x^{4}+2.2 \times 10^{8} x^{3}-1.4 \times 10^{7} x^{2}+3.1 \times 10^{5} x-1.6 \times 10^{3}$ & 3192.65 \\
$W_{\left(10 \%, 73^{\circ} \mathrm{C}\right)}=\int_{0}^{0.001 \cdot l} 1.5 \times 10^{9} x^{5}-7.3 \times 10^{8} x^{4}+1.3 \times 10^{8} x^{3}-9.3 \times 10^{6} x^{2}+2.8 \times 10^{5} x-1.5 \times 10^{3}$ & 3167.14 \\
$W_{\left(15 \%, 73^{\circ} \mathrm{C}\right)}=\int_{0}^{0.001 \cdot l} 2.3 \times 10^{8} x^{4}-8.6 \times 10^{7} x^{3}+1.04 \times 10^{7} x^{2}-3.9 \times 10^{5} x+3.2 \times 10^{3}$ & 3181.76 \\
$W_{\left(20 \%, 73^{\circ} \mathrm{C}\right)}=\int_{0}^{0.001 \cdot l} 1.9 \times 10^{9} x^{5}-8.98 \times 10^{8} x^{4}+1.6 \times 10^{8} x^{3}-1.1 \times 10^{7} x^{2}+3.4 \times 10^{5} x-2.1 \times 10^{3}$ & \\
\hline
\end{tabular}

The table above shows that the value of the work (corresponding to energy consumption) performed during briquetting, under certain conditions, of the forest residue shredded chips weighing $200 \mathrm{~g}$, ranged from 2118.45 to $3181.76 \mathrm{~J}$. For comparative purposes, the ob- 
tained results were unified, referring to their values as a mass unit. The action is presented using Formula (4).

$$
W_{B}=\frac{W_{(\tau, \varphi)}}{m}
$$

The calculated average value of the unit energy consumption during briquetting (WB) was $0.14 \mathrm{MJ} \cdot \mathrm{kg}^{-1}$. The measured value of the energy consumed during the compaction of wood materials can be compared with the test results presented in the available literature. The average unit value of energy consumption during the briquetting of pine sawdust with $8 \%$ moisture was $0.033 \mathrm{MJ} \cdot \mathrm{kg}^{-1}$, and in the case of compacting the raw material with $20 \%$ moisture, this value was $0.016 \mathrm{MJ} \cdot \mathrm{kg}^{-1}$. On the other hand, during the compaction of poplar sawdust with a moisture content of $8 \%$, the average value of unit energy consumption was $0.034 \mathrm{MJ} \cdot \mathrm{kg}^{-1}$, and with a moisture content of $20 \%$ it was equal to $0.020 \mathrm{MJ} \mathrm{kg}^{-1}$ [33]. The unit energy consumption for the compaction of birch sawdust with humidity $12 \%$ ranged from 0.023 to $0.051 \mathrm{MJ} \cdot \mathrm{kg}^{-1}$ [12]. The quoted results are much lower than those obtained as a result of the tests carried out for this study, which could have been caused by the smaller chamber diameter $(15 \mathrm{~mm})$ or the smaller mass of the thickened raw material $(2 \mathrm{~g})$.

\section{Discussion}

The realized scope of the study consisted of the selection of the values of the parameters influencing the compaction process and the durability of the resulting briquettes from the fragmented logging residues. The research material was characterized by its irregular composition, which included shredded particles of pine needles, small twigs, and bark. The non-uniformity of the composition completely distinguished the analyzed raw material from the materials currently used in the commercial production of briquettes, such as sawmill chips. The obtained results were compared with the values available in the subject letter, some of which were described for the first time.

In light of the laboratory tests and statistical analyses, it was estimated that the moisture of the compacted material should be in the range of $10-15 \%$. The presented range was compared with the values found in the literature, confirming the validity of the maintained moisture content of the raw material. Similar results were obtained by scientists, who, in the course of their research, thickened shredded corn cobs with a moisture content of $10 \%$ [34] and lupine meal with a moisture content of 13-14\% [35], as well as shredded wheat straw, barley straw, corn, and rose millet with a moisture content of $12-15 \%$ [6].

The literature describes studies of similar plant materials, where the concentrated fractions were 1.8, 5, 10, and $15 \mathrm{~mm}$ long [28]. When comparing the conducted analyzes with the cited literature studies, a certain similarity in the method of compaction can be observed. The literature also describes the process of aggregating rice straw, for which the average unit value of WB energy consumption during compaction [28] was lower by $0.05 \mathrm{MJ} \cdot \mathrm{kg}^{-1}$, and amounted to $0.096 \mathrm{MJ} \cdot \mathrm{kg}^{-1}$. In addition, a lower unit energy consumption was obtained during the compaction of wheat straw [36], where the WB value, depending on the diameter of the chamber $(12-18 \mathrm{~mm})$ and material moisture (10-18\%), ranged from 0.02 to $0.05 \mathrm{MJ} \cdot \mathrm{kg}^{-1}$. The average unit value of WB energy during the compaction of sugar miscanthus meal with 10-20\% moisture was $0.022 \mathrm{MJ} \cdot \mathrm{kg}^{-1}$, while for Virginia mallow with $10-22 \%$ moisture it was $0.029 \mathrm{MJ} \cdot \mathrm{kg}^{-1}$ [12].

At a temperature of $22{ }^{\circ} \mathrm{C}$, the maximum compaction force was achieved by shifting the piston by about $227 \mathrm{~mm}$, and at a temperature of $73{ }^{\circ} \mathrm{C}$, by about $246 \mathrm{~mm}$. This means a higher density of the biomass at higher temperatures. Based on the assumption that in both cases the same amount of biomass was used to carry out the aggregation test, it can be concluded that at a higher temperature, the material is denser, and the resulting briquette is therefore characterized by a higher specific weight. The observed phenomena may result from the liquidation of some substances contained in the raw material, thus improving the degree of its concentration. 


\section{Conclusions}

The use of wood waste as fuel reduces the burden on the environment by reducing the emission of pollutants into the atmosphere. Forest waste biomass can be a valuable raw material for briquette production. Because of the method used to obtain the material, forest biomass is distinguished by a diversified composition (bark, needles, wood, and young shoots) and irregular physical properties. The analysis of the research material was limited only to the logging residues of the Scots pine species (Pinus sylvestris L.). The research was aimed at determining the most advantageous, within the assumed limits, process parameters and the proper preparation of raw material for the process of manufacturing briquettes from the forest residue shredded chips.

The energy consumption values corresponding to the total work of the briquetting process performed under certain conditions $W_{(\tau, \varphi)}$ were analyzed in the context of the selection of the most appropriate environmental parameters. The selected mix with acceptable performance parameters should be characterized by the lowest unit energy consumption during the briquetting process. This analysis did not take into account the energy used to maintain the assumed process temperatures.

The impact on the process and the resulting briquette of the analyzed material and process parameters (moisture, particle size composition, and temperature) required the use of an appropriate method and measuring apparatus [37]. The measurement was carried out in a specially prepared compacting head [38], which allowed for recording the pressure and displacement of the piston. Additional studies were conducted in standardized devices by applicable standards and measurement procedures. Research on the strength of briquettes and the impact of individual parameters on the briquetting process (temperature and humidity) are described in the scientific dissertation [39]. Continuation of the research with the use of the previously estimated optimal production environment and the prototype compacting head may consist of introducing a binder as an additional component of the briquette. This would reduce the pressure applied to the piston and increase the strength of the structure. Future research will assume the development of a mathematical model that can serve as an algorithm in a computer program to calculate the flow of biomass in the extrusion process.

Author Contributions: Conceptualization, K.R.; methodology, K.R. and M.D.; software, K.R.; validation, K.R., J.B., and W.R.; formal analysis, K.R.; investigation, K.R., J.B., W.R., and M.D.; resources, K.R. and M.D.; data curation, K.R.; writing—original draft preparation, K.R., W.R., and M.D.; writingreview and editing, K.R. and M.D.; visualization, K.R.; supervision, K.R.; project administration, K.R.; funding acquisition, J.B. All authors have read and agreed to the published version of the manuscript.

Funding: This research received no external funding.

Institutional Review Board Statement: Not applicable.

Informed Consent Statement: Not applicable.

Conflicts of Interest: The authors declare no conflict of interest.

\section{References}

1. Roman, K.; Barwicki, J.; Hryniewicz, M.; Szadkowska, D.; Szadkowski, J. Production of Electricity and Heat from Biomass Wastes Using a Converted Aircraft Turbine AI-20. Processes 2021, 9, 364. [CrossRef]

2. Journal of Laws of 2015. Item 317-Journal of the Polish Republic. Pos. 317 Regulation of the Prime Minister of 2 March 2015 Amending the Regulation on Defining Templates of Reporting Forms, Explanations as to How to Fill Them in, and Templates of Statistical Questionnaires and Surveys Used in Statistical Surveys Established in the Program of Statistical Surveys of Official Statistics for 2014. p. 5. Available online: https://www.gov.pl/documents/528248/541918/Ustawa_o_pracy_na_morzu_engv2 .pdf/7218abd8-9240-bc65-aec4-a2a2bd2baa87 (accessed on 16 February 2021).

3. Isobe, Y.; Yamada, K.; Wang, Q.; Sakamoto, K.; Uchiyama, I.; Mizoguchi, T.; Zhou, Y. Measurement of Indoor Sulfur Dioxide Emission from Coal-Biomass Briquettes. Water Air Soil Pollut. 2005, 163, 341-353. [CrossRef]

4. Roman, K.; Borek, K.; Karwat, Z. Study of Compressibility in the Raw Materials Recycling. Inżynieria Materiałowa 2020, 41, 17-20. [CrossRef]

5. Hejft, R. Ciśnieniowa Aglomeracja Materiałów Roślinnych; Politechnika Białostocka: Białystok, Poland, $2002 ;$ p. 7. 
6. Mani, S.; Tabil, L.G.; Sokhansanj, S. Effects of compressive force, particle size and moisture content on mechanical properties of biomass pellets from grasses. Biomass Bioenergy 2006, 30, 648-654. [CrossRef]

7. Husain, Z.; Zainac, Z.; Abdullah, Z. Briquetting of palm fibre and shell from the processing of palm nuts to palm oil. Biomass Bioenergy 2002, 22, 505-509. [CrossRef]

8. Holm, J.K.; Henriksen, U.B.; Hustad, J.E.; Sorensen, L.H. Toward an understanding of controlling parameters in softwood and hardwood pellets production. Energy Fuel 2006, 20, 2686-2694. [CrossRef]

9. Holm, J.K.; Henriksen, U.B.; Wand, K.; Hustad, J.E.; Posselt, D. Experimental verification of novel pellet model using a single pelleter unit. Energy Fuel 2007, 21, 2446-2449. [CrossRef]

10. Xia XSun, Y.; Wu, K.; Jiang, Q. Modeling of a straw ring-die briquetting process. BioResources 2014, 9, 6316-6328.

11. Busse, W. Das Verdichten von Halmgutern mit Hohen Normaldrucken Fortschritt-Berlin VDI-Z; Reihe 14: Hamburg, Germany, 1964.

12. Kulig, R.; Skonecki, S.; Gawłowski, S.; Zdybel, A.; Łysiak, G. Oddziaływanie ciśnienia na efektywność zagęszczania trocin wybranego drewna miękkiego. Acta Sci. Pol. Tech. Agrar. 2013, 12, 31-40.

13. Frączek, J.; Mudryk, K.; Wróbel, M. Nakłady energetyczne w procesie brykietowania wierzby Salix viminalis L. Inżynieria Rolnicza 2010, 3, 45-52.

14. Maheshwari, R.C.; Chaturvedi, P. Bio-Energy for Rural Energisation; Concept Publiahing Company: New Delhi, India, 1997; p. 110059. ISBN 81-7322-673-8.

15. Mitchual, S.J.; Frimpong-Mensah, K.; Darkwa, A.N. Effect of species, particle size and compacting pressure on relaxed density and compressive strength of fuel briquettes. Int. J. Energy Environ. Eng. 2013, 4, 1-6. [CrossRef]

16. Kers, J.; Kulu, P.; Aare Aruniit, A.; Laurmaa, V.; Križan, P.; Šooš, L.; Kask, Ü. Determination of physical, mechanical and burning characteristics of polymeric waste material briquettes. Est. J. Eng. 2010, 16, 307-316. [CrossRef]

17. Sergeev, P.V.; Beletskiy, V.S. Briquetting the Carbon Phase from the Sludge Ponds at the Anzhersk Deposit ISSN 1068-364X. Coke Chem. 2013, 56, 282-285. [CrossRef]

18. Bruhn, H.D. Pelleting Grain and Hay Mixturies. Agric. Eng. 1973, 36, 330-3319.

19. Busse, W. Das Verdichten von Halmguterm mit hohen. Norm. FB VDJ 1966, 1, 121.

20. Matthies, H.J. Nevore Erkerintnisseaut dem gebiet das Verdichtens von Halmgut mit hohen. Norm. Grund. Landtech. 1966, $23,1-87$.

21. Naboru, K. The Compression and Solidity of Plant Materials; Laboratory of Agricultural Maschinery: Kyoto, Japan, $1967 ;$ p. 22.

22. Reece, F.N. Power requirements for forming wafers in closed Traus. ASAE 1967, 2, 131-150. [CrossRef]

23. Schwanghart, H. Heun und Strohpressen und die Anwendung in Arbeitsverforen. Landtechnik 1974, 9, 43.

24. Demirbas, A. Physical properties of briquettes from waste paper and wheat straw mixtures. Energy Convers. Manag. 1999, 40, 437-445. [CrossRef]

25. Obidziński, S.; Hejft, R. Wpływ parametrów aparaturowo-procesowych na wartości nacisków zagęszczających w procesie granulowania pasz. Inżynieria Rolnicza 2007, 5, 313-319.

26. Chen, W.H.; Kuo, P.C. A study on torrefaction of various biomass materials and its impact on lignocellulosic structure simulated by a thermogravimetry. Energy 2010, 35, 2580-2586. [CrossRef]

27. Kaliyan, N.; Morey, R.V. Factors affecting strength and durability of densified biomass products. Biomass Bioenergy 2009, 33, 337-359. [CrossRef]

28. Yu, W.; Kai, W.; Yu, S. Effects of raw material particle size on the briquetting process of rice straw. J. Energy Inst. 2018, 91, 153-162.

29. Grzebieluch, W.; Ścigała, K.; Mikulewicz, M. Wpływ sposobu modelowania właściwości szkliwa na rozkład przemieszczeń, odkształceń i naprężeń w koronie zęba przedtrzonowego-analiza metodą elementów skończonych. Dent. Med. Probl. 2006, 43, 333-341.

30. Wang, W.; Wu, Y.; Wu, H.; Yang, C.; Feng, Q. Numerical analysis of dynamic compaction using FEM-SPH coupling method. Soil Dyn. Earthq. Eng. 2021, 140, 106420. [CrossRef]

31. Roman, K.; Borek, K.; Mazur, K. The characteristics of briquetting process with resistance sensors usage. Przeglad Elektrotechniczny 2019, 95, 98-101. [CrossRef]

32. Borkowski, G. Badania Właściwości Mechanicznych Brykietów Węgla z Biomasa; Postępy Nauki i Techniki 2: Lublin, Poland, 2008.

33. Skonecki, S.; Kulig, R.; Potręć, M. Ciśnieniowe zagęszczanie trocin sosnowych i topolowych-parametry procesu i jakość aglomeratu. Acta Agrophysica 2011, 18, 149-160.

34. Kaliyan, N.; Morey, R.V. Densification characteristics of corn cobs. Fuel Process. Technol. 2010, 91, 559-565. [CrossRef]

35. Grochowicz, J.; Andrejko, D.; Mazur, J. Wpływ Wilgotności i Stopnia Rozdrobnienia na Energię Zagęszczania i Wytrzymałość Brykietóz Łubinowych; AR Lublin: Lublin, Poland, 2014; p. 96.

36. Skonecki, S.; Laskowski, J. Wpływ średnicy komory i wilgotności słomy pszennej na parametry zagęszczania. Acta Agrophysica 2012, 19, 415-424.

37. Grover, P.D.; Mishra, S.K. Biomass Briquetting: Technology and Practices, Food and Agriculture Organization of the United Nations, Bangkok, Field Document No. 46, ss 48. 1996. Available online: http:/ /leehite.org/biomass/documents/Biomass\%20 Briquetting\%20Technology\%20and\%20Practices\%20FAO.pdf (accessed on 12 January 2021).

38. Roman, K. Dobór Parametrów Technicznych Procesu Brykietowania Biomasy Leśnej. Ph.D. Thesis, Warsaw University of Life Sciences WULS, Warsaw, Poland, 2017; pp. 1-155.

39. Orisaleye, J.; Ojolo, S.; Ajiboye, J. Mathematical Modelling of Die Pressure of a Screw Briquetting Machine. J. King Saud Univ.-Eng. Sci. 2020, 32, 555-560. [CrossRef] 